\title{
Crisis in Theological Education
}

\section{Fake News or a Real Crisis?}

By Kris Veldheer, Catholic Theological Union; Dr. Kelly Campbell, Columbia Theological Seminary

ABSTRACT The presenters used a slide show to explain their research into the crisis in theological education. This research was based on an extensive review of the literature and used the grounded theory method to conduct interviews, to receive qualitative data. Beyond just reporting the findings, the presenters also gave attendees a glimpse into the nuts and bolts of doing this type of research.

\section{SUMMARY OF PRESENTATION}

Based on research into a perceived crisis in theological education, we offered some factors based on our review of the literature that we thought pointed to an actual crisis in theological education. Two of these factors were institutional identity and financial struggles. Although in doing our research we found several other studies done on similar aspects of this topic, the research gap we identified was that no one had done a qualitative study on this topic. Thus, we developed a grounded theory study based on the factors we uncovered in the literature, which led to actual data from the field of theological education. Further, we wanted to hear from voices within theological education to see if "lived" experience actually matched the literature of the field.

As part of the presentation, we shared the outline for our qualitative study, including our initial working explanation. We also took session attendees through the nuts and bolts of how we did the actual study, such as how we found the participants and how we analyzed the interviews. This was important information to share, since it 
described in part how we reached our outcomes. Likewise, we shared the demographics and denominational affiliations of our participants.

After laying the foundation, the study's research questions were displayed and explained. Included in our explanation were how we formed the research questions and some of the changes we anticipate making to the questions as we expand our research in Catholic and Evangelical seminaries. Finally, we shared the three broad findings of our study with those present. Those included outside and inside factors, as well as leadership factors. We closed by outlining what we learned and the next stages of our research. 


\section{Indexing the Theologico- Political}

By Evan Kuehn, Trinity International University; Shawn Goodwin, ATLA

ABSTRACT Political theology is an important and growing field of theological research, which has also attracted the attention of political scientists, philosophers, and social theorists. This interest has led to different and often ambiguous definitions of what political theology actually is. In addition, related subfields like liberation theology, public theology, and critical theory are often associated with political theology, making categorization challenging. It is important that theological librarians understand the changing terrain of theological-political inquiry in order to better provide access for their research communities.

In this paper, we present findings about the range of current description practices for books and journal articles related to political theology. We share preliminary explorations in mining cataloged resources for subject headings related to political theology, as well as full text of titles in HathiTrust for clusters of words that can be modeled as topics. These tools can help librarians to better understand the research literature they are describing, and engage with it more actively.

\section{INDEXING THE THEOLOGICO-POLITICAL}

Political theology is an important and growing field of theological research, which has also attracted the attention of political scientists, philosophers, and social theorists. This interest has led to different and often ambiguous definitions of what political theology actually is. In addition, related subfields like liberation theology, public theology, and critical theory are often associated with political theology, making categorization challenging. It is important that theological librarians understand the changing terrain of theological-political inquiry in order to better provide access for their research communities. 
In this paper we share preliminary explorations in mining cataloged resources for subject headings related to political theology, as well as full text of titles in HathiTrust for clusters of words that can be modeled as topics. These tools can help librarians to better understand the research literature they are describing, and engage with it more actively.

\section{WHAT IS POLITICAL THEOLOGY?}

Part of what makes political theology an interesting test case is how variable it can be as a field of study. Political theology often describes a number of quite various subfields and methodological approaches. We will begin with a short discussion of some of the primary uses of the term.

Political theology tends to include some sense of intersectionality or interdisciplinarity, which we see signaled in its name as dealing with "theology" and "politics." Cavanaugh and Scott offer this definition in the introduction to the Blackwell Handbook to Political Theology:

Theology is broadly understood as discourse about God, and human persons as they relate to God. The political is broadly understood as the use of structural power to organize a society or community of people... Political theology is, then, the analysis and criticism of political arrangements (including cultural-psychological, social and economic aspects) from the perspective of differing interpretations of God's ways with the world. ${ }^{1}$

Another commonly quoted definition, from Jan Assmann, also highlights the dual aspect of the field by understanding political theology as examining the "ever-changing relationships between political community and religious order, in short, between authority and salvation." 2

On the other hand, political theology is often rooted in political practice itself by means of association with a particular political stance, context, or end. The primary example of this is liberation theology, which might also be associated with contextual theologies such as black theology, Mujerista theology, Dalit theology, Minjung theology, etc. 
Another older example of contextually situated political theology is Christian Socialism. This designation was more common at the end of the nineteenth and beginning of the twentieth century and often corresponds with what we refer to today as political theology. Notably, the journal Political Theology began life with the subtitle "a journal of Christian socialism," although it doesn't include this anymore.

Political theology is also defined in terms of a particular object of study, usually one that offers a theological ground for political life: sovereignty, authority, glory, legitimacy, etc.

Political theology is also very often engaged with liberalism and secularism, because both of these present a situation where the theological content of political life is not explicit. Political theology is often opposed to liberalism and secularism, or presented as a genealogical critique of them.

\section{WHY SHOULD WE THINK ABOUT POLITICAL THEOLOGY?}

First, it is an emerging field. While political theology has been around for a while, over the past few decades it has experienced a significant surge in publications, new journals, etc. It is important from the standpoint of collection development librarianship to be aware of important new trends in theological fields, and topic modelling and subject heading analysis can assist in better understanding new developments.

As an interdisciplinary field, political theology often eludes clearcut categorization. A good deal of literature that is recognizable as political theology does not bear a heading that says as much on the title page.

Important literature in political theology often predates description of them as such. How do we interact with the metadata for these items?

\section{CONTROLLED VOCABULARIES}

In order to better understand the description of political theology literature, we will examine three important controlled vocabularies: the Library of Congress Subject Heading Authorities, the ATLA Religion Database (RDB) subject headings, and subject headings in the HathiTrust Collection. 


\section{LCSH AUTHORITIES}

The LCSH Authorities provide a helpful diachronic look at description practices for political theology because they include the year that each subject heading was established. Below are fifteen important subject headings for political theology texts. While "Political Theology" itself is only added in 1998, important alternative subject headings appear in the 1980s, especially "Liberation Theology" and "Religion and Politics.” Throughout the 1990s, an increase in description of contextual theologies related to political theology is notable, and in the 2000s this trend continues along with variations (e.g., "in literature" or "and race"). "Public Theology" is also recognized as an important subject that is in many ways synonymous with political theology.

- Liberation theology - 1986

- Secularization (Theology) - 1986

- Religion and politics - 1986

- Christian Socialism - 1986

- Minjung theology - 1989

- Womanist theology - 1994

- Mujerista theology - 1996

- Political theology - 1998

- Black theology - 2000

- Christian Sociology - 2003

- Social Gospel - 2005

- Liberation theology in literature - 2006

- Postcolonial theology -2010

- Public theology - 2010

- Political theology and race -2011

\section{SUBJECT HEADINGS IN THE RELIGION DATABASE}

The Religion Database of ATLA provides a unique window into the application of these related subject headings to articles and essays that are indexed. ${ }^{3}$ 


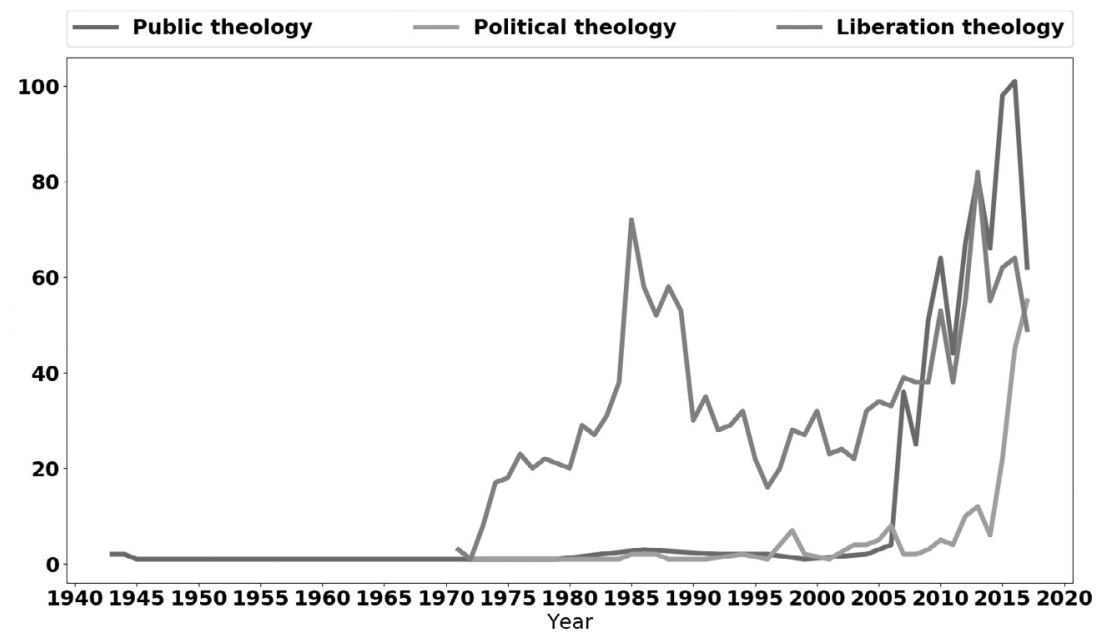

Comparing three of the central political theology headings

The general timeline of how the subject headings have been applied in to articles published in the various years shows the relative popularity of the topics in the material of the time. One curiosity is that Public Theology was added to the Religion Database before Political Theology, which accounts for its greater usage. This is in contrast to the LCSH, where Public Theology was added later.

\section{SUBJECT HEADINGS ASSOCIATED WITH POLITICAL THEOLOGY}

The five most common subject headings associated with Political Theology in the Religion Database are as follows:

1. Politics and Christianity, 55

2. Liberation theology, 24

3. Public theology, 21

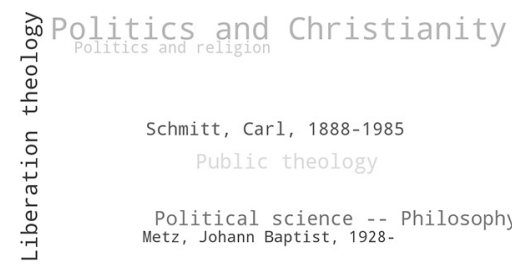

4. Political science-Philosophy, 19

5. Schmitt, Carl, 1888-1985, 15

An Association Wordcloud for Political Theology 


\section{SUBJECT HEADINGS ASSOCIATED WITH PUBLIC THEOLOGY}

The five most common subject headings associated with Public Theology in the Religion Database are as follows:

1. Theology-Methodology, 114

2. Politics and Christianity, 105

3. Social ethics, Christian, 77

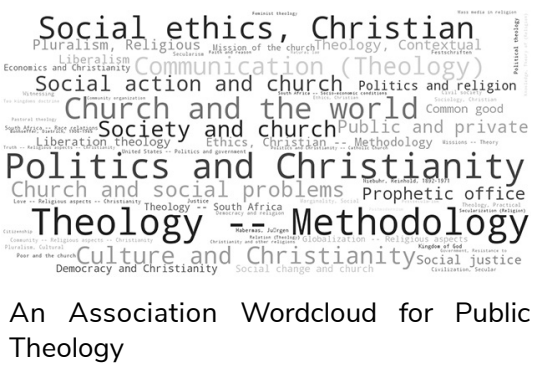

4. Church and the world, 73

5. Communication (Theology), 49

\section{SUBJECT HEADINGS ASSOCIATED WITH LIBERATION THEOLOGY}

The five most common subject headings associated with Liberation Theology in the religion database are as follows:

1. Theology-Methodology, 128

2. Theology-Latin America, 112

3. Poor and the church, 111

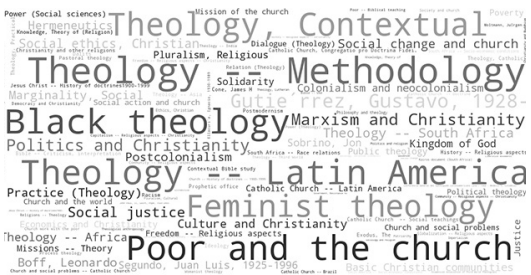

An Association Wordcloud for Liberation Theology

4. Black theology, 110

5. Theology, Contextual, 98

\section{SUBJECT HEADINGS IN THE HATHITRUST DATA}

We created a collection on HathiTrust of nearly 20,000 volumes. ${ }^{4}$ These volumes were narrowed down to around 10,000, and then we gathered the subject headings from OCLC for this narrower subset. Below, we have broken down these volumes into the fifteen most common topic headings by year.

While some subject headings are prominent over all decades (e.g., Politics and government, theology), we see "World War, 1914-1918" in the literature during the decade after the Great War. Liberation theology 


\begin{tabular}{|c|c|c|}
\hline $\begin{array}{l}1900-1919 \\
59 \text { items }\end{array}$ & $\begin{array}{l}1920-1939 \\
59 \text { items }\end{array}$ & $\begin{array}{l}1940-1959 \\
147 \text { items }\end{array}$ \\
\hline $\begin{array}{l}\text { Literature: } 9 \\
\text { Politics and government: } 7 \\
\text { Literature-Collections: } 6 \\
\text { Literature-Bibliography: } 6 \\
\text { World history: } 5 \\
\text { Speeches, addresses, etc: } 4 \\
\text { Clergy: } 3 \\
\text { Philosophy: } 3 \\
\text { Encyclopedias and } \\
\text { dictionaries: } 3 \\
\text { Compromise (Ethics): } 3 \\
\text { Clergy—United States- } \\
\text { Biography: } 2 \\
\text { World politics: } 2 \\
\text { Political parties: } 2 \\
\text { Political parties—France: } 2 \\
\text { Theology: } 2\end{array}$ & $\begin{array}{l}\text { Politics and government: } \\
8 \\
\text { Encyclopedias and } \\
\quad \text { dictionaries: } 7 \\
\text { Religion: } 4 \\
\text { Philosophy: } 3 \\
\text { Rhetoric, Ancient: } 3 \\
\text { Poetics: } 3 \\
\text { World War, 1914-1918: } \\
2 \\
\text { Civilization: } 2 \\
\text { Classical literature: } 2 \\
\text { Classical literature-- } \\
\quad \text { History and criticism: } 2 \\
\text { Church and state: } 2 \\
\text { Economic history: } 2 \\
\text { Encyclopedias: } 2 \\
\text { Protestantism: } 2 \\
\text { Church history-20th } \\
\text { century: } 2\end{array}$ & $\begin{array}{l}\text { Political science: } 13 \\
\text { Politics and government: } \\
11 \\
\text { Encyclopedias and } \\
\quad \text { dictionaries: } 9 \\
\text { Philosophy: } 7 \\
\text { Theology: } 6 \\
\text { Islamic civilization: } 4 \\
\text { Islam: } 4 \\
\text { Theology-Periodicals: } 4 \\
\text { Education: } 4 \\
\text { Philosophy-Periodicals: } 4 \\
\text { Kings and rulers: } 4 \\
\text { History: } 4 \\
\text { Social sciences: } 4 \\
\text { Periodicals: } 3 \\
\text { Church and state: } 3\end{array}$ \\
\hline $\begin{array}{l}1960-1979 \\
1238 \text { items }\end{array}$ & $\begin{array}{l}1980-1999 \\
4046 \text { items }\end{array}$ & $\begin{array}{c}\text { 2000-PRESENT } \\
2771 \text { items }\end{array}$ \\
\hline $\begin{array}{l}\text { Political science: } 80 \\
\text { Politics and government: } \\
67 \\
\text { Theology: } 53 \\
\text { Theology, Doctrinal: } 41 \\
\text { Civilization: } 35 \\
\text { Christianity: } 31 \\
\text { Political science_-History: } \\
28 \\
\text { Religion: } 25 \\
\text { History: } 23 \\
\text { Intellectual life: } 21 \\
\text { Theologie: } 19 \\
\text { Social conditions: } 18 \\
\text { Theology-Periodicals: } 17 \\
\text { Renaissance: } 16 \\
\text { Social sciences: } 16\end{array}$ & $\begin{array}{l}\text { Theology, Doctrinal: } 262 \\
\text { Politics and government: } \\
259 \\
\text { Theology: } 136 \\
\text { Liberation theology: } 128 \\
\text { Religion: } 128 \\
\text { Christianity: } 123 \\
\text { Civilization: } 110 \\
\text { Political science: } 105 \\
\text { Geschichte: } 81 \\
\text { Letterkunde: } 77 \\
\text { Theologie: } 77 \\
\text { Geschichte: } 75 \\
\text { Church and state: } 68 \\
\text { Christian ethics: } 68 \\
\text { Theologie: } 65\end{array}$ & $\begin{array}{l}\text { Politics and government: } \\
\quad 186 \\
\text { Religion: } 113 \\
\text { Civilization: } 78 \\
\text { Theology, Doctrinal: } 71 \\
\text { Christianity: } 69 \\
\text { Philosophy: } 68 \\
\text { Religion and politics: } 62 \\
\text { Political science: } 60 \\
\text { Christianity and politics: } 59 \\
\text { Theology: } 51 \\
\text { Political science-- } \\
\text { Philosophy: } 49 \\
\text { Intellectual life: } 48 \\
\text { Literatur: } 48 \\
\text { Religion: } 48 \\
\text { Literature: } 46\end{array}$ \\
\hline
\end{tabular}


is quite prominent in titles from 1980-1999, reflecting the same patterns as the LCSH and the ATLA database.

\section{TOPIC MODELING}

One way of exploring these subject headings and how they can be used for understanding the concepts and writing on political theology is through topic modeling. A topic model is a machine learning technique that groups words that commonly appear in the same context into a topic. The number of topics that a model fills with these bags of words is set in the initial parameters of the model. How many topics a researcher uses depends on the scope of the corpus, the length of the discrete texts fed into the model (the documents), the desired outcome, and the purpose of the model. ${ }^{5}$ Ideally, the topics should not overlap conceptually, nor should they be so broad as to be meaningless. For this project,we found that twenty-five topics for the corpus that we chose provided some of the most interesting topics. We chose thirteen books that cover a broad range of political theology. We also set the documents to be around 1,000 words. This provided more higher level topics than we anticipated, but it was very illustrative.

\section{BOOK SELECTION}

Here is the list of books we gathered from HathiTrust that we used as the basis for our topic model:

- Remembering Esperanza: a cultural-political theology for North American praxis-Mark Kline Taylor.

- Liberty, dominion, and the two swords: on the origins of Western political theology (180-398)-Lester L. Field, Jr.

- The scope of political theology-edited by Alistair Kee.

- A reader in political theology-edited by Alistair Kee.

- The Church as polis: from political theology to theological politics as exemplified by Jürgen Moltmann and Stanley Hauerwas-Arne Rasmusson.

- The politics of human frailty: theological defence of political liberalismChristopher J. Insole.

- Perspectives of a political ecclesiology-edited by Johannes B. Metz. 
- Liberation theology: human hope confronts Christian history and American power-Rosemary Radford Ruether.

- Mysterium liberationis: fundamental concepts of liberation theologyedited by Ignacio Ellacuría and Jon Sobrino.

- The king's two bodies: a study in mediaeval political theology-Ernst H. Kantorowicz.

- A genealogy of the corporation: articulating sovereign power and capitalism-Joshua Evdasin Barkan.

- Religion and violence: philosophical perspectives from Kant to DerridaHent de Vries.

- In search of a global ethics: theological, political, and feminist perspectives based on a critical analysis of JPIC and WOMP-Elisabeth Gerle.

\section{KEY TOPICS AND THEIR CONTENTS}

The topic model can be visualized. On the right side, the model displays some of the key terms for the model, and on the left side, the different topics are modeled to show the relative frequency of the topic in the corpus, and a general idea of how closely the topics overlap. ${ }^{6}$

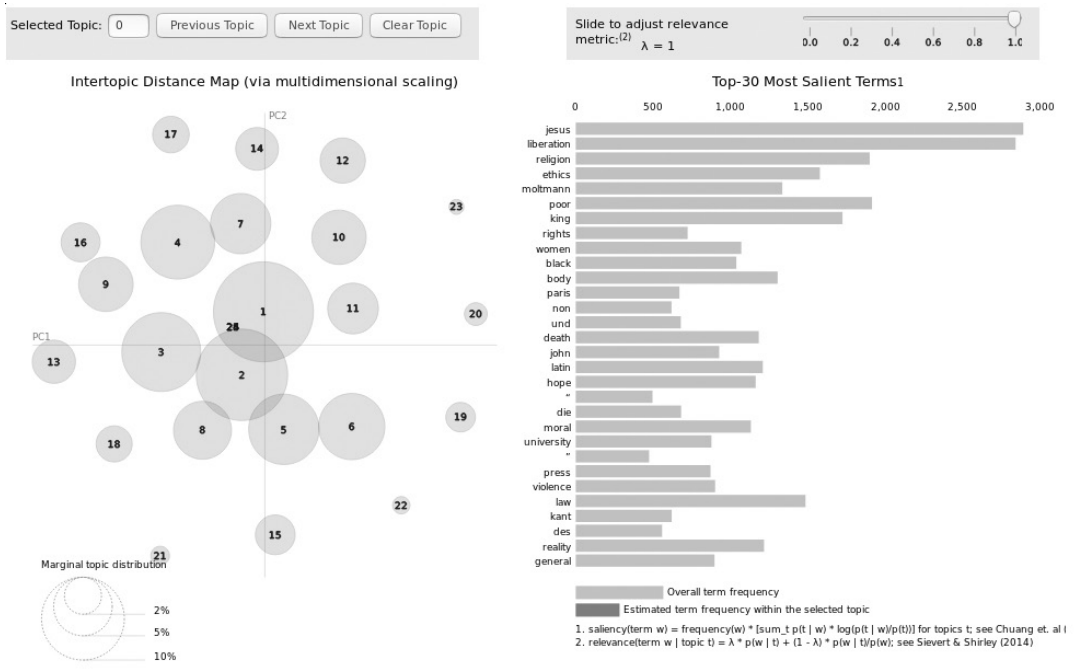

HathiTrust has extracted features from all of their scanned resources, and these sorts of extracted features lend themselves well 
to topic modeling. It allows the user to get a sense of the contents of a work, without reading it.

\section{CONCLUSION}

This exploratory study into topic modelling and subject heading analysis has been undertaken because of how much it can contribute to librarians' understanding of the theological literature, as well as their own engagement with it. Especially in the case of a complicated field like political theology, difficulties are present on both ends of the library ecosystem. When librarians work with patrons, reference interviews will not always be clear-cut, and the student may not even know what topic they need to research within the field of political theology. The existing collection, perhaps even archival material, includes literature relevant to political theology that often isn't described as such.

On the other hand, the taxonomical problem of understanding political theology begins with the task of controlled vocabulary and continues into the cataloging process. Political theology is interdisciplinary, broad, ambiguous, and changing, but still differentiable.

We also believe that there is more work that could be done in utilizing the tools of topic modeling in librarianship. Topic modeling can contribute to the discoverability of relevant items in the catalog. Many of the key resources for political theology were written before the creation (and widespread usage) of the Subject Heading, yet topic modeling can aid in the finding of resources, and even narrow down to the page key texts, for the study of a given topic. Topic modeling can also supplement metadata creation, when existing subject headings are inadequate. By way of anticipation on the part of indexers, topic modeling can help to trace potential trends by identifying prominent topic clusters that appear in more recent research. These tools and methodologies are transferable to other conceptual domains as well. We have chosen to focus on political theology because it provides an ideal test case, but other subfields of theology and religious studies would likewise be worth investigating. 


\section{NOTES}

1 William T. Cavanaugh and Peter Scott, "Introduction," in The Blackwell Companion to Political Theology (Malden, MA: Blackwell, 2004), 1.

2 Jan Assmann, Herrschaft und Heil: Politische Theologie in Altägypten, Israel und Europa (Munich: Carl Hanser Verlag, 2000), 15. Quoted in Hent de Vries and Lawrence Sullivan, eds., Political Theologies: Public Religions in a Post-Secular World (New York: Fordham University Press, 2006), 25; translation slightly modified.

3 For all of the code used in the preparation of this, please see http://e2dubba.github.io.

4 The collection can be found here: https://babel.hathitrust.org/ cgi/mb?a=listis\&c=1154484.

5 Micah Saxton has a helpful introduction to topic modeling: https://msaxton.github.io/topic-model-best-practices/.

6 For an interactive version of this model see http://e2dubba. github.io. 